\title{
THE PORTRAIT OF CHARACTER BUILDING IN 'TWILIGHT' FILM SCRIPT THROUGH ETHICAL VALUES
}

\author{
Sohibul Hairi \\ (sobibulhairi08@gmail.com)
}

Pusat Pengembangan Bahasa inggris

Universitas Negeri Maulana Malik Ibrahim Malang

\begin{tabular}{ll} 
ARTICLE & ABSTRACT \\
\hline Keywords: & Literature is a social phenomenon that is associated with writers, readers, and \\
related aspects of human life that is expressed in a literary work. In this view, \\
when someone attempts to analyze drama script to comprehend more about the \\
drama, to conduct a discourse analysis on drama plays a significant role in the \\
success of the analysis. Script or screenplay is one of literary work. There is 18 \\
character education in Indonesia according to Panduan Pendidikan Karakter, \\
Kemendikas 2010. They are: Religious, Honest, Disciplined, Hard Working, \\
twilight film script \\
Creative, Independent, Democratic, Curious, Nationalistic, Patriotic, Sportive and \\
respectful, Inclusive and Communicative, Peace-loving, Studios, Caring and \\
Compassion, Empathetic, Responsible. This study is aimed at two primary \\
purposes: (1) to investigate the moral values in 'Twilight' film script, (2) to \\
investigate the moral values to build someone's character. This study was carried \\
out the script of Twilight film written by Melissa Rosenberg. To achieve two \\
objectives, the data were analyzed by collecting and reviewing the document. After \\
moral values have been collected, they are analyzed and categorized the moral \\
values that could be implemented to build a student's character. The result of the \\
research is that there are some moral values in Twilight film script that could be \\
implemented to build student's character, they are (1) Honest, (2) Independent, (3) \\
Curios, (4) Patriotic, (5) inclusive and Communicative, (6) peace-loving, (7) \\
Empathetic and (8) Responsible. Those eight characters are a good character that \\
could be implemented to build the students' character. Suggestion proposed based \\
on the result analysis toward moral value in Twilight film script should be used as \\
one of the references. In education, especially for teachers, it is imperative to build \\
the students character.
\end{tabular}

\section{INTRODUCTION}

Texts as the extension of language come in various forms, from the simplest to the most complicated one. Memos, articles, drama scripts, novels, and reference books are included in texts. Drama or play is also one form of literary work, has always been an interesting subject to be discussed. Many people view drama as a reflection or a mirror of human life. Everything converted into a drama is the effort of human intelligence to make use of the language into written form with a set of 
intentions and purposes. Romeo and Juliet by Shakespeare are one example of a very successful and popular drama not only among artists but also those of ordinary people who give little attention to literary work.

Literature is a social phenomenon. That is associated with writers, readers, and related aspects of human life that is expressed in a literary work. Literature as a social phenomenon lies not only in terms of its creation but also on the nature of the work itself. Therefore, studying literature is learning life. That means that the study of human, life, culture, ideology, disposition, even regarding other issues related to broader human life (Semi, 1993:53).

In this view, when someone attempts to analyze drama script to comprehend more about the drama, to conduct a discourse analysis on drama plays a significant role in the success of the analysis. This analysis is because the context of situation covers the all verbal and nonverbal goings on in the text, which lead to the understanding of what is the drama about.

Script or screenplay is one of literary work. The script is written text that provides the basis for film production. The script usually includes not only the dialogue spoken by the characters but also a shot-by-shot outline of the film's action. Screenplays may be adapted from novels or stage plays or developed from original ideas suggested by the screenwriters or their collaborators. They generally pass through multiple revisions, and screenwriters are called on to incorporate suggestions from directors, producers, and others involved in the filmmaking process. First drafts often include only brief suggestions for planned shots, but by the date of production, a screenplay may evolve into a full shooting script, in which action and gestures are explicitly stated.

Twilight is one of the famous novels written by Stephanie Meyer. Twilight was adapted into a

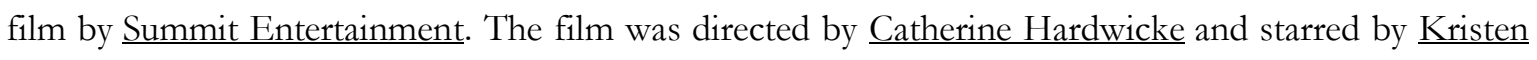

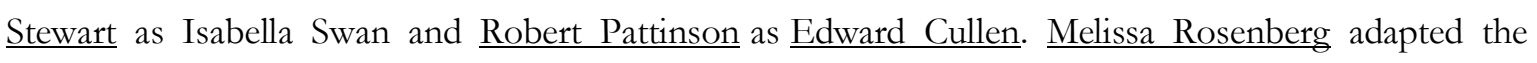
script.

The researcher chooses this object of research the script of 'Twilight' film because every people especially teenager love this film, it means this film is familiar for them. The researcher is sure that there are many moral values we can get from this movie, especially to build national character.

Our first president, one of the founder of Indonesian Republic, Bung Karno asserts that nation should be built by putting character building in the first place, since this character building that will make Indonesia become a big, glorious, victorious and prestige country (Afifi, 2013).

Due to the consideration above, the researcher is interested in conducting a study on "The Portraits of Character Building in 'Twilight' Film Script through Moral Values." 
JEASP

Journal of English for Academic and Specific Purposes

Volume 2 Number 1, June, 2019

There are two statements of problems in this study; they are:

a. What are the moral values in 'Twilight' film script?

b. What are the moral values to build someone's character?

In line with the study above, the objective of the study are:

a. To investigate the moral values in 'Twilight' film script.

b. To investigate the moral values to build someone's character.

\section{METHOD}

Qualitative research is all about exploring issues, understanding phenomena, and answering the questions. Sherman and Webb say qualitative research in education has come into vogue. Moleong (1991:3) qualitative research is a research which does not deal with a number, but in written and oral words from the object of the study. In this study, the researcher uses a descriptive qualitative method as a research design.

Qualitative research is a field of inquiry in its own right. A complex, interconnected family of terms, concepts, and assumptions surround the term qualitative research (Denzim and Lincoln, 1994:1).

The instrument is the researcher herself who gained and collected the data directly by reading the film script. Arikunto (1996:136) says that an instrument is a device for people to gain data and collect the data. Bogdan \& Biklen (1994:4) say qualitative research has an original setting as the direct source of data and the researcher is the crucial instrument such study of moral value in the Twilight film script itself. The researcher reads and understands the script before collecting and analyzing data.

The source of data in this research is 'Twilight' film script written by Melissa Rosenberg. The version script was taken from wwm.raindance.co.uk/site/picture/.../Twilight.pdf and retrieved on October $20^{\text {th }}, 2013$. The researcher is interested in this source because this film is one of the favorite movies in 2009. The researcher is sure every teenager knows this film because this study is designed in response to the students' questions.

Data collection is systematically procedures and standard to acquire the intended data. In collecting data in this research, first, the researcher reads 'Twilight' film script. Second, the researcher finds out the relevant data which matched to the statement of the study. Then the researcher analyzes 
JEASP

Journal of English for Academic and Specific Purposes

Volume 2 Number 1, June, 2019

the collected data and concludes them. The researcher finally retypes all data that have been chosen and selected based on the original quotation existing in Twilight film script.

In this study, first, the researcher reads and understands the script. After reading the script, the data are collected and then analyzed. The researcher applies the procedure proposed by Miles and Hubberman (1984) in which data collection, data reduction, data display, and conclusion drawing take place interactively.

According to Bogdan \& Biklen (1998:157), data analysis is the process of systematically searching and arranging the interview transcript, field notes and other material that researcher accumulates to increase his understanding of them and to enable him to present what he has discovered to others.

\section{FINDINGS AND DISCUSSION}

\section{FINDINGS}

There are some moral values in 'Twilight' film script and the moral values to build someone's character. The researcher found the data from Twilight script, which contents ethical values. The researcher reads Twilight script then and analyses each dialogue.

\section{Moral Values in Twilight Film Script}

The moral values found in Twilight script are:

\section{Honesty}

Honesty is a character based on an effort to make he/she be a trusted person in his/her statement, action, and work, whether to him/herself or others.

Edward's honest showed in this dialogue when he tells Bella the truth that he is a vampire, though it is hard he tries to tell the truth.

\section{EXT. FOREST - DAY}

Bella stands amid the trees, waiting. Then the SOUNDS OF THE FOREST abruptly drop out. A predator is near. Edward appears behind her. She does not turn around. A beat. 
JEASP

Journal of English for Academic and Specific Purposes

Volume 2 Number 1, June, 2019

As the sun hits him... EDWARD'S SKIN sparkles as if embedded with thousands of tiny diamonds. He is magnificent, shimmering, like a statue carved from glittering crystal. He moves toward her.

Edward: This is what I am.

Bella : You're... beautiful...

Edward (appalled): Beautifu? I'm a killer, Bella. This is the skin of a killer.

Bella : I don't believe that.

Edward: Because you believe the lie. The camouflage. I'm the world's most dangerous predator. Everything about me invites you in - my voice, my face, even my smell. As if I need any of that...

Edward: As if you could outrun me. As if you could fight me off.

Bella : I trust you. (Page 50)

\section{Independent}

Independent is behavior or attitudes that not easily depend on someone else to complete his/her task.

Independent, it is shown in the communication between Bella and her dad when he asks Bella to join other people, but Bella says she enjoys with herself just like her dad. It is showed in this dialogue.

Charlie: Just... you should be around people. I leave you alone too much.

Bella : (with genuine affection) I've never minded being alone. Guess I'm a lot like my dad that way. (Page 70)

\section{Curious}

Curious is attitudes and actions are always working to find out more in depth and extend from something he learned, seen, and heard. 
JEASP

Journal of English for Academic and Specific Purposes

Volume 2 Number 1, June, 2019

Bella's curiosity shows when Edward saves her from the car accident when Bella sees Edward far from the place she stands, but suddenly he saves them so quickly. It makes Bella wants to know how Edward can save her.

\section{INT. HOSPITAL - RECEPTION - DAY}

Bella: Can I talk to you for a moment? (off his nod) How did you get over to me so quickly?

Edward: I was standing right next to you.

Bella: You were next to your car, across the lot.

He steps closer to her. His expression turns icy hard.

Edward: No, I wasn't.

She won't be bullied. Steps closer to him.

Bella: Yes. You were.

Edward: You're confused. You hit your head.

Bella: I know what I saw.

Edward: And what, exactly, was that?

Bella: You stopped that van. You pushed it away.

Edward: No one will believe that.

Bella: I wasn't planning to tell anyone.

This registers with Edward. They're inches from each other, the tension thick.

Bella: I just want to know the truth.

Edward: Can't you just thank me and get over it?

Bella: Thank you.

A long beat as they look at each other, angry, defensive... and without a doubt, attracted.

Edward: You're not going to let it go, are you? 


\section{JEASP}

Journal of English for Academic and Specific Purposes

Volume 2 Number 1, June, 2019

Bella: No.

Edward (turns, walks away): Then I hope you enjoy disappointment.

Bella: Why did you even bother?

He stops, a beat. Looks back at her, unexpectedly vulnerable.

Edward: ... I don't know. (Page 28)

\section{Patriotic}

Patriotic is the way of thinking and acting that shows high honour toward language, environment, social, culture, economic and politic of one's own country. It showed when Rene asks Bella join her move to Philadelphia but Bella refuses because she loves Forks

Rene : Phil's working hard. We're looking around for a house to rent, in case it becomes permanent. You'd like Jacksonville, baby.

Bella : Actually, Forks is kind of growing on me. (Page 71)

Another dialogue shows that Bella's mom does not change her mind to asks Bella to join her, but Bella still wants to stay in Forks, because she loves Fork as her hometown.

Rene : Jacksonville is always sunny and you'll have your own bathroom...

Bella : Mom, wait. I want to live in Forks. I have Dad... (re: the get well cards) ... and friends... (Page 98)

\section{Inclusive and Communicative}

Inclusive and communicative is the act that shows happiness when he or she talks, interact, and works together with someone else.

It is showed when Eric kindly helps Bella to go around school because Bella is a newcomer.

Eric : You're Isabella Swan, the new girl. Hi. I'm Eric. The eyes and ears of this place. Anything you need. Tour guide, lunch date, shoulder to cry on.

(Bella just looks at him. Is he for real?) 


\section{JEASP}

Journal of English for Academic and Specific Purposes

Volume 2 Number 1, June, 2019

Bella : I'm kind of the "suffer in silence" type.

Eric : Good headline for your feature - I'm on the paper, and you're news, baby, and front page.

Bella : I -- no, I'm not news -- I'm, seriously, not at all --

Eric : Whoa, chillax. No feature.

Bella (relieved): Would you mind just pointing me toward Mr. Varner's class?

He leads her away, enjoying the attentive stares, as she cringes from them --

Eric : You've missed a lot of the semester, but I can hook you up - tutor, cliff notes, medical excuse... (Page 7)

Next dialogue Rene shows her pay attention to her daughter when she asks about Bella's school activity.

\section{EXT. GAS STATION/GARAGE - NIGHT}

Rene talks on a pay phone, her dead cell phone in her hand.

In the b.g., Phil and an Attendant work on the Subaru engine.

Rene : Ok, I didn't lose my power cord. It ran away. Screaming. I literally repel technology now.

Bella smiles, missing her mom. Rene feeds the phone quarters.

Rene : Now, tell me more about your school, baby. What are the kids like? Are there any cute guys? Are they being nice to you?

Bella : (a beat, lying) they've all been really... welcoming. (page 16).

\section{Peace-loving}

Peace loving is act, utterance, and attitude that cause someone else feel happy and save toward his/her presence. It is shown in this dialogue

Edward and his family have agreement they doesn't hurt people, they prefer hunt the animal to hunt the human instead. 


\section{JEASP}

Journal of English for Academic and Specific Purposes

Volume 2 Number 1, June, 2019

Edward: Me, and my family, we're different from others of our kind. We're not nomadic, we have a permanent home. We only hunt animals. We've learned to control our thirst... (Shaking his head) But you - your scent, it's like a drug to me... my own personal brand of heroin.

Bella : (realizing) Oh... I thought you hated me when we met.

Edward: I did. For making me want you so badly. I'm still not sure I can control myself. He reaches her again.

Bella : I know you can. (Page 54)

\section{Empathetic}

Empathetic is the act and attitude of someone who always wants to give contributions and pays attention to someone else and people in the society that need help.

Esme and dr Cullen show their attention to Edwards life who found his love for the first time after he waits for a hundred year.

INT. CULLEN HOUSE - LIVING ROOM - SAME

Esme and Dr. Cullen look out the window. Edward's LAUGHTER filters inside to them; Esme, in turn, smiles.

Esme : She's brought him to life.

dr. Cullen $\quad$ : He's been alone too long... but how can it end well?

Esme : Alice has been wrong before.

dr. Cullen $\quad$ : Not often.

Esme turns to Dr. Cullen, gentle but absolutely firm.

Esme $\quad$ : Carlisle. Bella is what he wants. It will work out.. (Page 66)

The other dialoge shows Laurent's attentive to the Cullen, when he warns the Cullen about James and her woman.

EXT. CULLEN HOUSE - NIGHT 


\section{JEASP}

Journal of English for Academic and Specific Purposes

Volume 2 Number 1, June, 2019

Edward, Emmett and Alice rush Bella from the truck to the house... but freeze when the door opens and Laurent exits. They immediately take defensive positions but Dr. Cullen appears.

dr. Cullen : He came to warn us. About James.

They back down slightly. Laurent address Dr. Cullen.

Laurent $\quad$ : I've grown tired of his games. But he's got unparalleled senses. Absolutely lethal. I've never seen anything like him in three hundred years ... And the woman, Victoria, will back him. Don't underestimate her.

Dr. Cullen nods thanks. Laurent looks at Edward, apologetic.

Laurent : I'm truly sorry for what's been unleashed here.

And he moves off, disappearing into the woods. (Page 82)

\section{Responsible}

Responsible is attitudes and behaviour of a person to carry out the duties and obligations, he should do, to self, society, environment (natural, social and cultural), the state and Almighty God.

This dialoge shows the responsibility of each family member that has to protect each other.

Edward: Esme, Rosalie, put these on so the tracker will pick up Bella's scent.

Rosalie : (dropping the clothes) Why should I? What is she to me? Just a danger you've inflicted on us --

Dr. Cullen: (spinning on her) Rosalie. Bella is with Edward. She's a part of this family now. And we protect our family. (Page 84)

\section{Love Science}

Love science is a way of thinking, act, and behave that shows higher loyalty, care, and appreciation toward science.

This dialogue shows that Edward and Bella love science, it proves when their teacher asks them to analyze the onion root tip cells. They immediately know the kind of phase.

INT. BIOLOGY CLASS/HALLWAY - DAY 
JEASP

Journal of English for Academic and Specific Purposes

Volume 2 Number 1, June, 2019

Mr. Molina (to the class)

Onion root tip cells! That's what's on your slides. Separate and label them into the phases of mitosis. The first partners to get it right win... the golden onion!

He excitedly holds up a spray painted onion. Everyone just looks at him. He's disappointed by their apathy.

Mr. Molina: Come on, people. Tick tock.

Everyone sets to work. Edward pushes the microscope to Bella, keeping his distance, his voice controlled.

She grabs the microscope defensively and snaps the first slide in, adjusting the lens. She's curt as she addresses him.

She glances at him but he just leans far away, his face tight. She looks back into the microscope.

Bella : Prophase. (She begins to remove the slide).

Edward: May I look? (She slides him the microscope. He glances through the lens.)

Edward: Prophase.

Bella (muttering): Like I said. (Page 21)

\section{Moral Values in Twilight film Script could be implemented to build Student's Character.}

Character is a person in a narrative work of arts (such as a novel, play, television series or film. Character education is an umbrella term loosely used to describe the teaching of children in a manner that will help them develop variously as moral, civic, ethical, mannered, behaved, non-bullying, healthy, critical, successful, traditional, compliant or socially acceptable beings.

The purpose of character building is to build children's personality to be the right person, good society, and good citizen. According to Battistich character education has the essential additional benefits of helping youth to develop positive personal and social attitudes and skills that will help them to lead satisfying and productive lives, and to become active and capable citizens in our democratic 
JEASP

Journal of English for Academic and Specific Purposes

Volume 2 Number 1, June, 2019

society. The goals of character education are thus mostly the goals of raising good children: youth, who understand, care about, and act upon the core ethical values (such as diligence, compassion, integrity, and fairness) that make for a productive, just, and democratic society.

Moral values found in Twilight Film script that could be implemented to build student's character are as follow:

1. Honest

2. Independent

3. Curious

4. Patriotic

5. Inclusive and Communicative

6. Peace-loving

7. Empathetic

8. Responsible

9. Love Science

The researcher in the previous point, has elaborated the explanation of each character building.

\section{DISCUSSION}

This chapter covers the discussion about some points of the ethical value in the Twilight film script which can be built in the school role in the civil society and role in the government that related to national characters and its constraints itself.

\section{The Moral Value in "Twilight” Film Script through Character Building}

The moral values through character building found in Twilight film script are:

\section{Honest}

Honesty is act / deed of someone that is based on the effort to make her / himself can be believed / trusted in utterance, and action by someone else. Having a character of honest is perfect and very important for people. Being honest sometimes it is so difficult to do. However, for some people, they prefer to be honest than a lie. It shows when Edward being honest to Bella who he is. Though it is hard to say, he takes a risk. Therefore, the character building "Honest" is essential to be applied in Indonesian education. Students must have honest so that they can be a right person. 


\section{Independent}

Independent is behavior or attitudes that not easily depend on someone else to complete his/her task. Human being is a social creature; we cannot be separated from other people, but in real life, people should not depend on other people. The students have to be independent. They must have their hearts to make their decision on their life. These points are in line with the supporting given by the curriculum Centre (2009: 9-10) where independence is one of its value.

The ministry of education states detailing briefly five points that should be planted to the students; it is behavior or attitude that not easily depend on someone else to complete his/her task.

\section{Curious}

Curious is attitudes and actions are always working to find out more in depth and extend from something he learned, seen, and heard. It shows in dialogue, Bella's curiosity when Edward saves her from far away. It means one's act and attitude that always tries to find out something that is learned, seen and heard deeply and widely. The character building "Curious" is significant for students; when they must have curiosity so that they try to learn everything they need.

\section{Patriotic}

Patriotic is the way of thinking and acting that shows high honor toward language, environment, social, culture, economic, and politic of one's own country. It showed when Bella's mother asks Bella to join her move to Philadelphia, but Bella refuses to join her because they love a place where he was born and grown. The students should have proved this "Patriotic". They have to love and then be proud of their country, language, and culture.

\section{Inclusive and Communicative}

Inclusive and communicative is the act that shows happiness when he or she talks, interact, and works together with someone else. It is showed when Eric kindly helps Bella to go around school because Bella is a newcomer. Indonesian students should apply to this character building.

\section{Peace-loving}

Peace-loving is an act, utterance, and attitude that cause someone else feels happy and saves toward his/her presence. Edward and his family have an agreement; they do not hurt people; they prefer to hunt the animal to hunt the human instead. The students should have "peace-loving," they have to make some friends, they make their friend feel happy and save when they are around and do not hurt each other. 


\section{Empathetic}

Empathetic is an act and attitude of someone who always wants to give contributions and pays attention to someone else and people in the society that need help. Esme and dr Cullen show their attention to Edwards life who found his love for the first time after he waits for a hundred year. The researcher thinks that parents and teacher should give an example of how they give attention to other people. Based on Indonesian national character and culture education, empathetic is one of character building values point 17. So the point character building "Empathetic" is also vital for students to be applied.

\section{Responsible}

Responsible is attitudes and behavior of a person to carry out the duties and obligations, and he should do, to self, society, environment (natural, social and cultural), the state and Almighty God. It proves when Cullen as a head of the family shows the responsibility of each family member that has to protect each other. The point of responsibility in these data above are in line with the statement of Samani et al. (2012:41) character is the way of thinking and behavior, which is unique to every individual to live and cooperate, whether in family, society, and nation. A person with excellent characteristic is an individual who could make a decision and able to respond to her/his decision. They also have to build the character of response so that they will always do the best in things they have to do.

\section{Love Science}

The point of Love science that has been explained by the researcher in the previous chapter is in line with supporting theories given by the Curriculum Center (2009: 9-10) that gave 18 value of character building that based on religion, Pancasila, culture, and purpose of national education. Love science is a way of thinking, act, and behave that shows higher loyalty, care, and appreciation toward science.

\section{Moral Values that could be implemented to Build Student's Character}

From the analysis that has been discussed above, the moral values that can be implemented to build students' character are honest which is someone's' attitude that is based on the effort to make her / him-self can be believed / trusted in utterance. Independent is behavior that not quickly depends on someone else to complete her/his task. Curious is one's act and attitude that always tries to find out something that is learned, seen, and heard deeply and widely. Patriotic is the way of thinking and acting that shows high honor toward language, environment, social culture, economic and politic of one's own country. Inclusive and Communicative is the act that shows happiness when he or she talks, 


\section{JEASP}

Journal of English for Academic and Specific Purposes

Volume 2 Number 1, June, 2019

interacts, and works together with someone else. Peace-loving is an action, utterance, and attitude that cause someone else feels happy and saves toward his or her presence. Empathetic is an act and attitude of someone who always wants to give contributions and pay attention to someone else and people in the society that need help. Responsible is an act and attitude of someone to conduct his or her duties that he or she should do for him / her, people, environment, nation, and God. Moreover, last is Love Science.

\section{REFERENCES}

Arikunto, S. (2000). Prosedur Penelitian: Suatu Pendekatan Praktek. Jakarta: Rineka Cipta.

Afifi. (2013). Pengantar Kajian Sastra. Jakarta: Pinus.

Bogdan, R. C., \& Bikken, S.P. (1998). Qualitative Research for Education: An introduction to Theory and Method $3^{\text {rd }}$ edition. USA: A Viacom Company.

Denzin, N. K., \& Yvonna S. L. (2009). Handbook of Qualitative Research. Terj. Dariyatno dk.k. Jogjakarta: Pustaka Pelajar.

Perrine, Laurence. (1984). Literature, Structure, Sound, and Sense. New York: Thompsons Wadsworth.

Novick, Bernard et al. (2002). Building Learning Communities Character. Library of Congress Catalogingin-Publication Data. USA

Semi, A. (1990). Metode Penelitian Sastra. Padang : Angkasa.

mwn.raindance.co.uk/site/picture/.../Twilight.pdf retrieved on October 20, 2013 